\title{
Mobility and population dynamics
}

\author{
Lothar Smith and Paul Hebinck ${ }^{*}$
}

\section{Introduction}

For others who are retrenched the problems are smaller as they may still be young and do not yet have families to care about like myself. However I am an old man ... to lose your job at my age [58 years] is difficult. But with retrenchment, and generally increasing unemployment, the elder generations have no such resources to set aside, and cannot afford to plough. This money cannot come from the children even if these do have a job in Johannesburg, Port Elizabeth or Cape Town, as they only think about their girlfriends and the alcohol in the city. They forget about their rural homes, about their wives and about sending money for ploughing.

This quote from an interview in May 2000 with Mr Mangqila of Guquka points at key issues to be dealt with in this chapter, including the coming and going of people, the movements from town to rural home and vice versa, so typical of Guquka and Koloni, like many other villages in the former homelands. More specifically, we will analyse population dynamics and the shifts in homestead and family arrangements and address the processes that have shaped existing social-spatial relationships, whether kinship-related or not.

* The authors wish to thank Brice Gijsbertsen for supplying the census 2001 data for Guquka and Koloni. Nick Parrott gave valuable comments on the last draft. 
This chapter thus addresses how the livelihood transformations that were broadly identified in chapter 4 and are further described in chapters 12 and 13 have affected the homestead and the relationships among people. In the work of Hoernlé (1937), Soga (1931) and Lewis (1984) on pre-colonial rural settlements in present-day Eastern Cape, the homestead (umzi) was seen as constituting the basic unit of production and consumption, which also forms the basis for settlement in both villages (chapters 2 and 4). The umzi was posited as a group of kin-related households, each of which entails a male head with one or more wives who live together in one compound. These heads would recognise the leadership of the (male) head of one of the constituent households. Typically, the umzi constituted a cooperative work unit. This picture fits the pre-colonial period but only partly resembles contemporary reality. As we have seen in previous chapters processes related to migration have substantially altered the social composition of the homestead and the family but also the patterns of resource use. These social processes and transformations are embodied in the contemporary physical layout of the villages. Houses in a state of decay lie adjacent to recently erected houses built according to the latest urban architecture, and intensively cultivated gardens aside long neglected fields; these are symbols attesting to the influence of social change on the physical layout of the two villages. We will explore whether labour migration is the only factor that explains current social-spatial processes, or whether the 'household' is intrinsically characterised throughout time by continual changes in spatial, social and economic dimensions not necessarily related to migration of its members. To explore the relation between social processes and physical ones, we examine the basic demography of the two villages and the composition of the homesteads.

\section{Village demographics}

An essential feature of village demography is the steady increase in population size. On the one hand this has been due to natural growth. However it isalso the result of the influx of people from elsewhere through the forced removals of black people from areas demarcated as white by the South African government during the 1960s, 70s and 80s. Chapter 4 has shown that this influx particularly affected Guquka. Koloni did not receive any 'newcomers' and its population increase has been mainly due to natural population growth.

Table 11.1 summarises the available data on population growth. These data are compiled from a range of sources. Looking at the trends discussed in chapter 3 and summarised in Table 11.1 three distinct demographic periods can be discerned: (1) 1850s-1960s; (2) 1960s-1990s and (3) 1990s to the present. These periods are clearly separable from each other as they mark changes in the state of the region and related important events. Thus, the first period spans the time of settlement (1830s) of the region and leads up to the moment (early 1960s) when many blacks were forced to migrate to the region from surrounding areas. The second period is concurrent with the existence of the state of 
Ciskei. The third period starts when Apartheid was abolished and first democratic national elections were held (1994).

Table 11.1 Estimated population size, Guquka and Koloni, 1939-2004

\begin{tabular}{|c|c|c|c|c|}
\hline \multirow{3}{*}{ Year } & \multicolumn{2}{|c|}{ Guquka } & \multicolumn{2}{c|}{ Koloni } \\
\cline { 2 - 5 } & Population & $\begin{array}{c}\text { Number of } \\
\text { dwellings }\end{array}$ & Population & $\begin{array}{c}\text { Number of } \\
\text { dwellings }\end{array}$ \\
\hline 1939 & n.a. & $38(1938)^{\mathrm{f}}$ & $190^{\mathrm{a}}$ & $33^{\mathrm{f}}$ \\
1962 & n.a. & $78(1963)^{\mathrm{f}}$ & $329^{\mathrm{b}}$ & $56(1963)^{\mathrm{f}}$ \\
1991 & $650^{\mathrm{c}}$ & $127^{\mathrm{c}}$ & $514^{\mathrm{c}}$ & $95^{\mathrm{c}}$ \\
1996 & $460^{\mathrm{d}}$ & $122^{\mathrm{d}}$ & $315^{\mathrm{d}}$ & $97^{\mathrm{d}}$ \\
2001 & $300^{\mathrm{e}}$ & n.a. $^{\mathrm{e}}$ & $262^{\mathrm{e}}$ & n.a. \\
2004 & $187^{\mathrm{g}}$ & $125^{\mathrm{g}}$ & $224^{\mathrm{g}}$ & $133^{\mathrm{g}}$ \\
\hline
\end{tabular}

n.a: not available

Sources:

a) Ndlovu (1991)

b) Betterment Planning Commission (1962)

c) Republic of Ciskei Population Census (1991)

d) ARDRI Survey (1997)

e) Extrapolated from Republic of South Africa Population Census (2001)

f) Calculated from aerial photos (chapter 6)

g) Total number of people counted during update 2004 (Hebinck 2004)

We discuss only the most important changes for the first period, focusing more on the second and third period. In the period from 1850 to 1960 British Kaffraria, later designated the Ciskei, was sparsely populated. Thus Xhosa, Mfengu, Hottentots, British and other settlers were able to move in and settle the region, initially without much dispute (chapter 2). However an unabated migration of new settlers to the region led to increasing competition for resources, particularly grazing land, among these groups and thus to increasing conflict. The Xhosa were forced to steadily concede land to the Boers and English, who had also entered in alliance with the Mfengu. Their steady loss of land to these other groups took a turn for the worse when they heeded the call of Nongqawuse, a Xhosa prophetess, to destroy all their crops and kill their cattle, as this would drive 'the white man' back into the sea. Instead this act resulted in a large-scale famine (chapter 2), reducing the Xhosa population from about 105,000 in January 1857 to 26,000 by the end of 1858 (Switzer 1993), effectively ending their struggle against the white settlers. Concurrently, the British expanded their presence in British Kaffraria by bringing in military settlers to the region, who established new settlements such as Berlin and Stutterheim. Their influx saw the presence of white people increase from below one thousand in 1856 (less than $1 \%$ of the total population) to 53,888 (12.5\% of the total population) by December 1858 (ibid.). 
Turning to the population data for the twentieth century our analysis of individual magisterial districts (Table 11.2) shows that for the period of 1911 to 1936 the population substantially increased by $38 \%$. Thereafter, the population grew at a much slower pace of $3 \%$ from 1936 to 1951 (ibid.). However, the two districts incorporating Guquka and Koloni actually experienced negative growth rates between 1916 and 1951. Population change in Victoria East District (Guquka) was strongly negative at $-26 \%$, while the Middledrift District (Koloni) also recorded a decrease with a $3 \%$ decline (Table 11.3).

Table 11.2 Population of African people in the Ciskei, 1911-1951

\begin{tabular}{|l|r|r|}
\hline Period & Numbers & Increase in \% \\
\hline $1911-1936$ & 120,889 & 38.14 \\
$1936-1952$ & 13,349 & 2.96 \\
$1911-1951$ & 134,238 & 42.35 \\
\hline
\end{tabular}

Source: Adapted from Switzer (1993), Table A7.2: 236

Table 11.3 Population change in the Ciskei 1916-1951; selected districts

\begin{tabular}{|l|r|r|}
\hline District/Period & Number & \% change \\
\hline \multicolumn{3}{|c|}{ Victoria East } \\
\hline $1916-1936$ & $-4,939$ & -33.5 \\
$1936-1951$ & 1,105 & 11.3 \\
$1916-1951$ & $-3,834$ & -26.0 \\
\hline \multicolumn{3}{|c|}{ Middledrift } \\
\hline $1916-1936$ & n.a. & n.a. \\
$1936-1952$ & -750 & -3.0 \\
\hline \multicolumn{3}{|c|}{ Ciskei as a whole } \\
\hline $1916-1936$ & 10,106 & 4.3 \\
$1936-1951-$ & 17,808 & 7.3 \\
$1916-1952$ & 27,914 & 11.9 \\
\hline
\end{tabular}

n.a. $=$ not available

Source: Adapted from Switzer (1993: Table A7.3: 237)

The discrepancy between the population growth for the Ciskei region as a whole and the population decline in the Middledrift and Victoria East districts can be explained by the fact that during this period the region was expanded to include areas which had strong population growth. The Tomlinson Commission 
(1955) confirmed that some magisterial districts within the Ciskei had recorded negative population growth.

Switzer (1993) examined the actual capacity of the Ciskei to absorb the African population from surrounding regions and concluded that between 1916 and 1951 this declined. Whereas in 1916 about 74\% of the region's resident population was living in the reserve, by 1936 this had been reduced to $63 \%$ and by 1951 it had further declined to $58 \%$. This decline in the capacity of the Ciskei region to provide a basis for a rural livelihood not only points to increasing population pressure on available resources but also to the increasing importance of income sources not based in the rural economy in the lives of villagers. This confirms what has been stated before: from the first half of the twentieth century onwards rural people began to look elsewhere for livelihood options, notably focusing on the urban and industrial economies of the country.

Koloni experienced an estimated annual growth of $3 \%$ for the period between 1939 and 1962. For Guquka the absence of population census data meant that we had to resort to changes in the number of dwellings and from this extrapolate changes in population. Our analysis suggests an average annual rate of increase of 4.4\% in the period 1938 to 1963 (chapter 7). These are growth rates which are considerably larger than in the Ciskei as whole. We can only hypothesize that at the time conditions in the two villages were quite favourable when compared to other parts of the Border/Ciskei region.

The second period, from 1960 until the early 1990s, encompassed the time of forced removals carried out by the state. Thus the mechanisation of agriculture on white farms, which made large numbers of farm workers redundant (Marcus 1989), resulted in these labourers being forced to move to the reserves. Other forced removals took place when parts of the Eastern Cape were reallocated to the Western Cape, which was restricted to whites, forcing Africans in these areas to move out to the reserves. Black people were also removed from locations in the East London metropolitan area. These forced removals followed on the Group Areas Act of 1950 and other actions implemented by the South African government that sought to reduce the number of black people in urban areas. Finally, people that were removed from Herschel and Glen Grey districts (referred to by Swizter as 'refugees') added to a general influx in the Ciskei.

Between 1970 and 1980 the Ciskei received more than 160,000 immigrants. In the same period districts such as Victoria East and Middledrift experienced population increases of $4.5 \%$ and $2.7 \%$, respectively (Switzer 1993), showing that this influx was unevenly distributed. Green and Hirsch (1982) argue that urban areas experienced especially high growth rates, rather than rural areas such as the districts of Victoria east and Middledrift. Thus their data show an urban population growth rate of $8.2 \%$ per annum for the Ciskei between 1970 and 1980, and a $4.0 \%$ growth rate for the rural areas. To express the nature of these demographic changes Kruger (1991: 39) referred to the Ciskei as the 'dumping ground for Xhosa refugees'. It is estimated that the Ciskei alone 
absorbed two-thirds of the Xhosa people who were forced to move from locations elsewhere in South Africa.

Koloni, which did not experience such dumping, recorded an average annual population growth rate of $2.3 \%$ for the period 1962 to 1991 . Interpretations of aerial photos suggest a similar population growth for Guquka for the same period, which is much lower than that of the previous period. However we add that as aerial photos and regional/district data constitute different sources of data, caution needs to be taken with respect to the reliability of our interpretations.

The third period, from the early 1990s until present, relates to a period in which previously maintained influx control measures were withdrawn. Thus in 1991 the Group Areas Act was withdrawn by the government. This last period has seen contrasting tendencies and, as it is also still ongoing, this makes it difficult for us to draw conclusive comments with regard to major processes that are at play.

Recent demographic data available for the two villages show a dramatic decline in population numbers (Table 11.1). This is partly explained by net outmigration of villagers who seek to pursue urban livelihoods. However, at the same time there is also a return migration of people who have returned to the village. Thus the population decline may also be related to other influences and one on of these must be HIV/AIDS. At the time we conducted our research we gave insufficient attention to this issue, not helped by the fact that the topic was much avoided when we tried to focus on it with villagers. As villagers often attributed deaths to causes other than HIV/AIDS, we have no numbers to support our analysis of the extent to which HIV/AIDS has influenced the village demography. However the increasing rate with which younger people are being buried points to an increasing effect of AIDS on village economies. Parker et al. (2000) point to multiple economic dimensions of the impact of HIV/AIDS on homesteads, arguing that it leads to income losses, increases household expenses due to expenditure on medicines, requires investments of other members of the homestead in the ill person to provide care, when these funds could have been used more productively. The death of the infected person imposes further expenses on the family for the organisation of a funeral and may result in the decision to remove children from school to compensate for financial losses. Parker et al. also argue that HIV/AIDS has a disproportional impact on rural women, notably AIDS widows in paternal systems, as they become stigmatised and lose rights to resources. This makes them and their children especially vulnerable. However, phenomena such as grandparents taking over the care of their grandchildren following the demise of their own children, or children caring for their siblings are also fundamental issues affecting rural economies (Drimie 2002, Parker et al. 2000).

One way to understand population dynamics is to look at the demographic profile of a village. The frequency with which rural homes are occupied or left vacant for varying periods of time also provides data which can help interpret 
these findings. Both dimensions provide evidence of the social transformations of homesteads in the two villages and later we argue for a differentiation between single homestead households ( $\mathrm{SHH}$ ) and multiple homestead households (MHH) to explain transformations of rural livelihoods and homesteads (De Wet and Holbrook 1997).

Figure 11.1 shows the demographic profile for the two villages in 1997. These two demographic profiles, especially that for Guquka, compare well with demographic trends for the Eastern Cape Province as a whole (Hutchinson et al. 2004, Table 2.1: 16).

Unfortunately, earlier data were not available to enable a comparison with these contemporary data. The figure clearly indicates the absence of the "thirty plus' generation, and the return of males of the generation that preceded it due to nation-wide retrenchments throughout the 1990s. The data also clearly illustrate that in both villages younger males in the 20-29 age group are still present in the village. They mainly depend on local casual work and support from their kin for their living (chapter 12). They seem to represent a 'lost generation' who, with few perceived opportunities to earn a living as migrants, have remained in the village, relying on income from odd jobs, pensions of elder members of their homesteads and/or remittances sent by a brother or sister who has managed to find an income 'in town'.
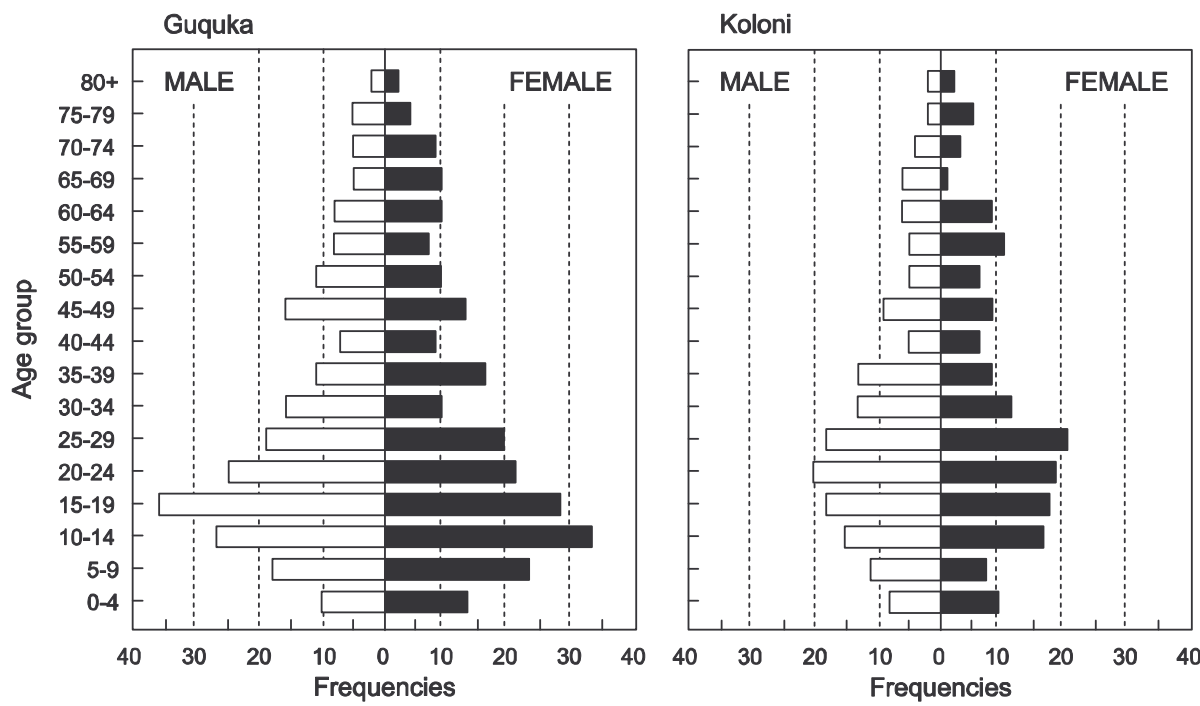

DEMOGRAPHIC PROFILES

Figure 11.1 The demographic profile of Guquka and Koloni in 1997

Source: ARDRI Survey (1997) 
The age structure of the villages also shows the predominance of the elder people, 60 to 80 years old, and of those older than 80 . Their presence points at the relative importance of pensions in providing for livelihoods, not only for these pensioners, but also for other members of their homesteads.

The situation in Guquka and Koloni also reflects a more recent trend of young women leaving the village, usually to obtain work or education outside the village. In doing so, some join their spouses who had preceded them. The demographic pattern of Guquka seems to represent a typical migration picture: men from the most productive age group (35 to 44 years) do not reside in the village. They usually return at the age of 40 and above. However, in the last fifteen years this general pattern seems to have been undermined by retrenchments from jobs in urban centres and industrial areas.

Another phenomenon in both villages reflected in Figure 11.1 is the presence of fewer young children (0-4 age group) than a 'normal' demographic composition would have indicated. This hints at out-migration of young parents with their children and confirms the recent institutional change in the nature of migration compared to prior decades when Apartheid regulations largely confined migration to male labour migrants. With the abolition of the pass laws the nature of migration has begun to take change from temporary labour-oriented migration to more permanent forms of migration, as young villagers seek to secure an urban life.

Parsons (1982), examining population data for South African urban areas, suggested that female migration from rural to urban areas has taken place before. He observed that the proportion of males and females leaving rural areas had changed from 4:1 in 1911 to $2: 1$ by 1936 . This he related mainly to a rising demand for female domestic labour amongst urban whites. At the same time increasing repression under Apartheid legislation seemed to have halted the further entry of black females into the urban labour market.

The more permanent migration of younger villagers with their children to urban parts of South Africa has also reduced the reduced possibilities for the older generation to look after these children (usually their grandchildren), a role which ensured the commitment of migrants to the well-being of their elders, as it also influenced the well-being of their own children (see also see Bank 2002).

At the same time the HIV/AIDS pandemic is once again reconfiguring these affiliations, as grandparents take up the role of caretakers of young children again when the parents of these children die. In this case there are few benefits for these elders to take on this role.

\section{The future is in the city}

"Why are you leaving the rural area?" was a question we regularly asked. Most female respondents in the villages saw migration as a major improvement because they could be closer to their husbands and be less fearful of being left behind in the village, their livelihood and relation to their husbands in constant 
jeopardy as many men found 'another woman' in town. The policy change has also enabled many female residents of the village (both single and married) to (re-)enter the urban labour market.

Mrs. Mandeya and her daughter-in-law explain the significance of wives migrating to town, sometimes also with their children:

We women want this [to move to the city] because it will stop our husbands from taking another woman there with whom he may also make some children. Eventually he will become trapped between the two houses, the two wives and his two families. As he finds it harder and harder to accommodate the needs of both families he might eventually decide to leave his real wife and only support his woman in town.

Mrs. Mandeya's livelihood trajectory is illustrative of what many widows experience. She told us that after an active life in Koloni she wished to retire with her children who reside in town. When we interviewed her in 2000, she informed us that her husband had passed away one year before. She still lived on her own and enjoyed a pension. However, unlike many other pensioners, none of her children or grandchildren stayed with her in Koloni, although her sons who worked in King William's Town visited her during the weekends. Some of her other children lived and worked in the more distant Port Elizabeth. Of these children, some were residing in a house bought by her late husband when he took up work in Port Elizabeth in 1952.

The late Mr. Mandeya started working as a migrant labourer in the mines in Johannesburg from 1946 until 1951. In 1947 he married Mrs. Mandeya. When he moved to work in Port Elizabeth she initially remained behind in Koloni to look after his parents but joined him in 1962. In 1979 she moved back to Koloni with the children. Mr. Mandeya had been able to buy a residential plot and fields from a family that left the village, and they built a house on this residential plot. She moved into it to bring up the children whilst he remained in Port Elizabeth until retirement in 1990, when he returned to Koloni.

In the meantime their children, upon reaching adulthood, had moved back to Port Elizabeth to seek work. Initially they shared the Mandeya house there but at present all but one of the five children have married and acquired their own residences. Recently Mrs. Mandeya joined her children in Port Elizabeth for a few months, staying at the house that originally belonged to her husband. One of her grandsons said: "She's right there. When she got there she did not need the attention of doctors anymore!"

When interviewed her in Koloni in 2000, her sons, John and Alfred, who had come to visit their pensioned mother, clearly conveyed that it is hard to get employment in Port Elizabeth. Nevertheless they prefer to remain there and not return to Koloni. They eke a living out of various temporary jobs and claim this is enough for them to live on. It supports them, their wives and their children. Nxoli, John's wife, explained that they do not want to return to the rural areas 
because it is impossible to get opportunities in a village like Koloni that would enable them to obtain "a flashy car, a nice house and good education for our children". Reality for her and John has, so far, proved to be quite different from these ideals. In the past few years that they had stayed in Port Elizabeth she had only been employed for three months in an 'ANC (government) employment scheme'. John was employed in a factory for some time but when he was retrenched two years ago, they remained unemployed for a long time. They had needed to get by on 'small jobs', such as petty trade. "Buying things cheap and selling these more expensive" enabled them to survive for two years until John was once again employed by the factory where he had worked earlier. Nxoli:

And that is my point. It is easier to survive in the city, even if you are unemployed, than in a rural area because there [in the rural area] you have to depend on your crops for survival. We do not want to live in a rural area ... we are going to stay in the city permanently! Now that things are looking better again for us, with my husband having employment, we are going to take away my mother [in law] to come and stay with us in Port Elizabeth. The clinics there are much better and she [that is her mother, LS/PH] can be near all her children again.

Indeed when we inquired after Mrs. Mandeya in 2004 the chairman of the residential committee confirmed that she had left 2 years ago and now stayed with her children. The house she had been staying in was now no longer inhabited, although it continued to be maintained. She was said to come to Koloni once a year.

The case of Mrs. Nthlabate is also informative regarding the drive to leave the village. Since 1987 the homestead consisted of her father, mother, herself, and most recently, her young child. In 1987 her two brothers and sister left Koloni, taking up residence in Mdantsane situated between King William's Town and East London.Until her father died in 1999, she had relied on his pension. Now, without this pension she has become dependent on the produce she can sell from the garden she cultivates. In managing the garden she is aided by a male cousin also staying in Koloni. She stressed that the financial support she receives from her two brothers and sister is minimal, as her two brothers are unemployed at present, and have not returned to the village since 1987. Her sister does return at times, but cannot offer much help. After a long silence she raised the hope that sometime soon a job opportunity will arise. She will take this opportunity and leave her child with the family of her mother. She does not wish to remain in Koloni. In 2004 she still had not found the golden opportunity and continued to remain in Koloni. She still worked in her home garden selling some of her produce. However, she has begun to receive a child support grant from the state. This has made her life a little easier she said, but the city continues to attract her. Mrs Nthlabate's case clearly underlines that the resources upon which her livelihood hinged, have gradually reduced in quality and com- 
position. The urban environment appeared as one with lots of opportunities, even for a short period of time only.

Finally, the migration to the city also results from the inability of some villagers to gain or negotiate access to resources such as arable land. Accounts of interviewed youths clearly emphasize that the terms under which key resources were accessible (such as sharecropping, chapters 6 and 8) and the lack of opportunities outside farming (chapter 12) push them to town, where there are more, and better, opportunities to earn a living. Xiliba, a youngster in Guquka who helped with collecting new and updated data in April 2004, added that there is not much to do in the village:

No work and not many peers to talk to. What do I do here; there is no future for me here. I have applied for a job and hope to get it soon. Now I do not even have money to go to the shebeen for a beer and meet others.

Taking the subject further it became clear that farming was not considered to be a proper job and part of a modern life style. "You work hard and there is hardly a return". Others youngsters expressed similar thoughts and one said that "if you come back next year, you will not find me here. I am in Cape Town then to go to school, and I will look for jobs there and probably never come back here". This aspect is treated in more detail in chapter 8.

The draw to the 'city lights' has led many villagers to establish themselves in urban areas. In fact, the youth follow the careers of their fathers. The difference between then and now is that some of the youths resented the control of those they referred to as the 'old families' who largely controlled the conditions to access arable fields (chapter 6 and 8 ).

\section{Rural security and the role of pensions and remittances}

The rural settlement, however, continues to provide social security to those who decide to remain in the village, but also to those whose efforts to secure an urban-based livelihood fail. Mr. Msiwa has felt this burden, and explained that having a large 'family' was not always beneficial. From the 1970s onwards most people in Guquka found it increasingly difficult to sustain their lives. As a consequence many re-evaluated their ties with fellow villagers, clan and even family members, deciding to focus only on those with whom reciprocity would be more certain. Thus most respondents complained that presently help from fellow villagers required payment. However, this did not only hold for neighbours and friends, but also for fellow members of the same clan and even family. Other villagers describe Mr. Msiwa as a kind and considerate man whom you can always approach for help with a problem, especially when you are a family member. However he commented:

After the Dabi's my family is the largest. The whole family lives in or near Guquka. Whenever anyone of them has a problem they turn to me first. Usually they come to 
ask for financial help concerning family problems like when someone has passed away. Issues such as not being able to afford the necessary money for hiring a tractor, or getting oxen for ploughing I do not try to solve because they are on a different level [of importance]. With the other problems I try to help. However I cannot help others in the village. Like we try and solve our own problems within the family, others must do the same.

A further example is that of Mr. Mxolisi, an unmarried man in his early forties. He explained that he had to return to Koloni despite having his own house in Dimbaza:

There are no jobs, or they are not good. My sister now works for a Chinese shoe factory in Dimbaza. She earns 3 Rand per hour only! Yet I have nothing. I am doing any job around Koloni but it is nothing. I am supported by my parents with their pensions. I wish to work their lands but we have not got that money ... we cannot afford to hire a tractor. The money needed for that is too much; no one can afford that, especially the pensioners who form the majority of this village, as they are already supporting their children.

\section{Social relations and the homestead}

The homestead and its social configuration have undergone significant changes in both villages (see also Bank 2002; Ngwane 2003). Today, both in Koloni and Guquka, one finds little evidence of previously existing cooperative working arrangements that were based on reciprocity, although a few arrangements still exist (chapter 8). Thus there is still evidence of wool farmers collectively marketing their wool in Koloni (chapter 9). The lending of cattle (ukusisa) also still occurs in both villages, to some extent also supported with remittances from urban incomes. Thereby other villagers take care of the cattle of migrants in their absence, and are provided with some of the calves these cattle bear. More recently this practice seems to have been adapted to respond to an increasing presence of widows who are unable to care for their cattle (Bennett 2002 and chapter 9).

Chapter 8 provided some evidence of the demise of cooperate labour arrangements for arable farming. In contrast, care-taker arrangements of residential properties are still common and, according to the current chairmen of the Residents Committee of Koloni, even increasing. These arrangements entail resident villagers watching over residential properties of family members or neighbours who have migrated. Table 11.4 below contains numerical evidence of such relationships.

Residence in homesteads has changed dramatically from a kin-based homestead, where certain tasks and responsibilities were carried out either collectively or according to a certain pattern of distribution (such as cooking, planting, ploughing, providing shelter, socialisation and security) to a more multi-local 
residence pattern. Kinship ties remain important, irrespective of where one resides and works, but the nature of these social relationships are of declining importance in extending support and providing indefinite, unconditional care to others. Contributing to this decline are changing gender and power relations and shifting livelihood conditions that have led people to earn a living elsewhere. For some people this is combined with increased options for a living that is based on resources not confined to the immediate village, as social pension schemes and remittances also play an important role for them. Regarding the homestead, one respondent in Guquka narrated that in the past the 'house' (homestead) was much bigger:

$[\mathrm{M}] \mathrm{y}$ brothers could get married and still live on the same plot as my parents ... until the end of the 1970s it was possible for the whole family to be cooking from one pot.

Furthermore other villagers such as neighbours would also be provided some of the food that had been cooked. Another respondent also argued that the role of the clan or the isidulo (extended family) had changed from encompassing and providing for the livelihoods of all its clan members, to a role where only on important cultural occasions, such as weddings and funerals, financial and other kind of support was being given to others of the isidulo. Similarly, employment opportunities elsewhere would first be relayed to one's direct family members, then to extended family members before being passed on to others. All respondents asserted during interviews we held with them that it was no longer possible to rely upon isidulo relationships alone. The situation of Miss Ntlangweni described earlier in this chapter points this out clearly, namely that even help from next of kin (brothers, sisters) is insecure.

Evidence from urban research in East London townships shows how many young women, once in town, turn their backs on their rural homes. Bank (2001) reports of women who preferred to remain in town and spend their income in clubs and on luxury commodities rather than providing it directly to the rural economy. Pouring money into a faltering agrarian economy is an unattractive and risky business for women in the city. Thus, they develop their relationships with fellow urban residents through church, grocery clubs, burial societies, saving clubs and credit associations. The presence of unfinished houses in Koloni's 'squatter settlement', many owned by young and unmarried mothers (chapter 4), is a reflection of this changing interest of female migrants.

When mapping out social networks with respondents in Guquka and Koloni, discussing who is important to them, these respondents named few, if any, people not belonging to their own extended family, especially when it came to those who supported their livelihoods. Even when we interviewed respondents who in the past had lived and worked outside the village, they also only identified family members as comprising their urban based relationships. This finding seems to confirm that the role of family, both urban and rural, for providing 
security to those in the villages is still regarded essential by villagers. Relationships with non-kin that were established outside the village do not seem to have any value in the village.

Mrs. Sonja described the change that has taken place in Guquka over the last fifty years in which the composition of the homestead changed from an extended, loosely arranged, social unit to a more nuclear form:

Before, the whole family was cooking from one pot. Even when the parents arranged a house for their son and his newly wed wife, who might not like to live in one place with his parents, they would still come together to cook and eat before going to their own houses ... The problem is that now it is impossible to all live together, as this would mean starvation. From the fields and the incomes contributed by the different members it is impossible to find a living for all because contributions are so irregular. That is why we have spread out to separate residential sites and own fields. Now that the fields are finished, however, people depend on incomes from elsewhere to survive.

While this comment referred especially to a change in local arrangements of livelihoods, its validity also extends to livelihoods encompassing multiple locations. Certainly the validity of her statement can be empirically ascertained in the prevailing composition of most homesteads. Ties at the local level, through kinship linkages, whilst still important, have been much reduced. None of the present homesteads in the villages approaches the size of homesteads which elder respondents described existing in the past. Nevertheless, strong variation in the actual composition of homesteads remains in terms of size, generations present, and extent of incorporated family ties.

In Koloni, the size of most homesteads seems not to have diminished appreciably over time. This is mainly attributable to the arrangement of residential sites, which were fixed from the start, implying that opportunities for expansion were always limited. The establishment of their own homesteads by offspring was in that way always encouraged and perceived by 'school' thought as an advancement, enabling looser social and economic arrangements. Only in the past decade has the size of the homestead, and more importantly also the presence of various generations in the village, changed due to a strongly declining role of local opportunities which has spured many of the younger members of the homesteads to leave.

De Wet and Holbrook (1997: 255) attempted to capture and understand the process of the coming and going of villagers between their rural village and town. They noted that, increasingly, homestead members reside and work somewhere else while maintaining ties with and contributing to the well-being of those in their original, rural homes. They thus suggested distinguishing between single homestead households (SHH) and multiple homestead households (MHH). An SHH represents a configuration where migrants still see themselves as having only one home, namely the rural homestead where they grew up, to which they send remittances and make return visits, and to which 
they assume they will one day return to retire. An MHH reflects the situation whereby members of the original rural SHH find a job in town, and unlike migrants in an SHH, set up their own, potentially permanent home there. Upon achieving an urban livelihood, and establishing ties with others in the town/city, their affiliation to the village slowly changes. They will maintain ties with their rural kin, particularly their own parents and siblings, sending money and goods or their children during school holidays, and also visiting the village for important cultural occasions (initiation rites, celebrations, funerals, weddings). However, these ties more often relate to social-cultural affiliations with the village and their kin than to direct economic interests.

The single homestead household ( $\mathrm{SHH}$ ) is exemplified by the homestead of Mrs. Tibana who lives at Guquka. Mrs. Tibana belongs to one of the original families of the village. She was born in Guquka and raised there by her mother, as one of six children, while her father worked in Cape Town. When she reached adulthood she was the last of these children to leave Guquka for urban areas. She joined a sister in Rustenburg and worked with her sister in an informal 'take-away'.

Her father, upon retirement, returned to the village and depended on a pension to support himself and his wife, also augmenting this income with agricultural activities until his health began to fail him and the related expenses required the bulk of his pension. His children were at this stage unable to provide much financial support from what they were able to earn elsewhere. With her father's health declining Mrs. Tibana decided to return to Guquka to take care of her parents in 1997, giving up her life and steady income to do so. She emphasized that she was the only child who was prepared to make this sacrifice.

Since the death of her parents she has remained in the village to occupy their house, supporting her children with an assortment of temporary and part-time jobs she is able to do around the village. Her brothers and sisters have always remained in town, seldom returning to Guquka and hardly providing her with any support through remittances or otherwise.

A typical MHH is that of Mr. Mcete in Koloni who was born and bred in Koloni. The eldest of five children, he never married nor had any children. At the time of our interview in March 2000 he was staying with his two brothers in the house of his parents, who had passed away some time before. Reaching adulthood he had gone to work in the mines and stayed for a long time in Johannesburg. However, in 1981 he suddenly returned to Koloni when he had been declared unfit for such work due to mine poisoning. As compensation for his illness he was provided with a health grant by the government, sufficient for subsistence needs.

Mr. Mcete's three brothers and sister had also left the village upon reaching adulthood. Two of his brothers had moved in with him in Johannesburg and had also begun to work in the mines. They also returned with him to Koloni in 1981, hoping that they could draw on their savings to expand their agricultural activi- 
ties. Instead they came to rely on local 'piece' jobs to gain an income, augmented with the grant which Mr. Mcete received. In the meantime, upon the death of her husband, Mr. Mcete's mother moved in with her daughter and her husband who were living in nearby King William's Town, to receive health treatment when necessary.

In 1998 Mr. Mcete's grant was taken away from him without any explanation. A disabled person, his options for gaining an income were limited to gardening in the house plot. Not eligible for an old-age pension for ten more years he and his brothers started to rely heavily on remittances they received on occasion from their mother (from her old-age pension), sister and their youngest brother (a civil servant in Bisho) to augment what they produced and earned locally.

The presence of SHHs and MHHs is clearly reflected in the frequency of occupation of homes throughout the year (Table 11.4). In 1997 there were 33 homesteads in Guquka who maintained a second residence in town. Of these, 8 had left all or some of their children in the care of others residing in Guquka. Most migrants lived in distant urban areas such as Cape Town, Port Elizabeth and Gauteng, and returned to Guquka maintaining links with their rural residence through weekly, monthly or annual visits.

Table 11.4 Reported frequency of occupation of rural residences in 1997 and 2004

\begin{tabular}{|l|r|r|r|r|}
\hline \multirow{2}{*}{ Frequency of occupation of the rural home } & \multicolumn{2}{|c|}{ Guquka } & \multicolumn{2}{|c|}{ Koloni } \\
\cline { 2 - 5 } & 1997 & 2004 & 1997 & 2004 \\
\hline Every night & 81 & 86 & 61 & 65 \\
Weekends & 1 & 0 & 5 & 2 \\
Once a month & 6 & 0 & 12 & 1 \\
Irregular & 0 & 2 & 5 & 2 \\
Once per year or less & 25 & 4 & 8 & 13 \\
Never (and/or caretaker arrangement) & 2 & 18 & 5 & 6 \\
Vacant or unusable & 6 & 15 & 1 & 44 \\
\hline Total & 122 & 125 & 97 & 133 \\
\hline
\end{tabular}

Source: Adapted from Van Averbeke et al. (1988a) and Hebinck (2004)

In Koloni all 35 homesteads who occupied their rural residence only during weekends, or less frequently, maintained a second residence in an urban area. Twenty-eight of these households had children, but only three left these children behind in Koloni in the care of relatives or neighbours. Distance between the urban residence and Koloni influenced the frequency with which households returned to their rural residence. Those staying in East London, or nearby urban centres, such as Alice, Middledrift, King William's Town and Dimbaza, usually travelled back and forth on a weekly or monthly basis. Others, who stayed farther away, limited their visits to once or twice a year. 
Families who have migrated out of the village for long periods usually leave their assets in the rural settlement such as their homes, livestock and land, in the care of neighbours or relatives. But there is also evidence of villagers who have left the village without making any arrangements with villagers regarding the maintenance, use and security of their resources in the village. The resulting underutilisation of these assets, particularly of arable fields, is contested by others who want to utilize these to pursue local, agriculture-related livelihoods (see also chapter 8).

The fluidity of the situation becomes clear when one compares the 1997 data with the 2004 update for the two villages. In both Guquka and Koloni more people were coming home to their village every night in 2004 than in 1997. However, for people who do not stay at the village on a daily basis (coming home every night), findings suggest a strong decline in their physical presence in the villages. Indeed in Koloni an astonishing 44 out of 133 homes had, either permanently or temporarily, become vacant, with some houses in a clear state of being abandoned (Table 11.4). In Guquka caretaker arrangements had become much more commonplace than before.

\section{Conclusion}

The chapter has discussed three contrasting demographic trends which clearly associate local demographics with migration and government policy. The first trend concerned the expansion of both villages, on the one hand due to natural population growth but also due to influxes of migrants from other parts of South Africa. The second trend concerned temporary migration to the mines and urban areas. The third, most recent, trend concerns the outflow of villagers, particularly younger generations, without it being clear whether they have intentions to return to the village.

This chapter has clearly revealed that migration has, for a long time, formed an important element in the lives and livelihoods of villagers. Thus, as was already discussed in chapter 4 , and as will be further substantiated in chapter 12 , migration needs to be examined in conjunction with the role of local economic activities, particularly agriculture. This concurs with the findings of chapters 8 and 9, namely that over the past century the economic role of agriculture declined as it has gradually been replaced with resources and incomes derived from outside the village, such as remittances from migrant family members and pensions (old age, illness, child care).

Especially for villagers who did not have sufficient access to local resources to maintain a local livelihood, temporary migration to the mines and urban areas formed the most viable alternative. This held especially for those who arrived in the Eastern Cape from other parts of South Africa during the 1960s and 1970s. However, also male villagers with access to local resources, notably arable land, preferred to go to the mines for some time, as this enabled them to generate savings which they could invest in agricultural activities, facilitating their 
livelihoods, and those of others in their homesteads, upon their return to the village.

Over the course of the twentieth century migration has changed socialeconomic configurations among villagers. This is due to increasing disparities in wealth: some villagers are able to farm their land, expand their herds and derive remittances from family members in other parts of the country on a regular basis. Other villagers need to resort to modest means for their survival. Changes in social relationships have also resulted from households establishing themselves in multiple locations, deriving their livelihoods from multiple sources. To protect these sources they have limited their involvement with other households in the village. And when they do engage with their fellow villagers they may do so through explicit, formalised arrangements. Thus changing social configurations, notably through migration, lead to strengthening linkages of rural with urban and national economies, but also seem to lead to a formalisation of village relationships.

Finally, and more recently, households have once again changed their configuration following the end of Apartheid, which ended restrictions on mobility, enabling villagers to choose where they want to live. This change has further compounded economic differences between homesteads, as it has resulted in more permanent forms of migration of villagers to urban areas, often involving their whole household and not just one or two members.

The out-migration of families has, thus far, not resulted in a severance of ties with the larger family who has remained in the village. However, given that it is generally the young, able-bodied who leave the village, local livelihoods do become further detached from agriculture and increasingly dependent on external resources. At the same time retrenchments and generally high levels of employment in urban areas have seen the rise of a reverse trend whereby villagers who migrated to urban areas have begun to reinvest in their social relationships with those in the village, in an attempt to safeguard their entitlement to local resources with the view that, at some stage, they might return to the village. This might be an involuntary movement, as with retrenchments, but could also be planned, as in the case of retirement. 